A

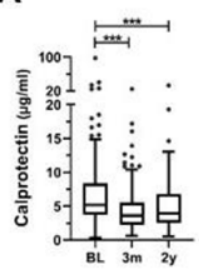

D

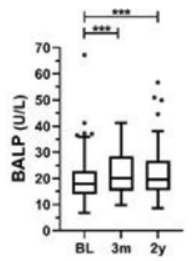

G

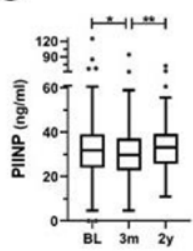

J

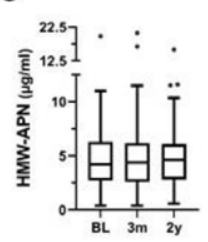

B

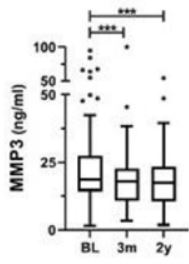

E

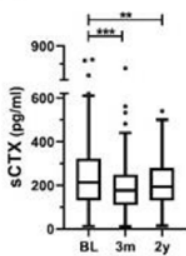

H

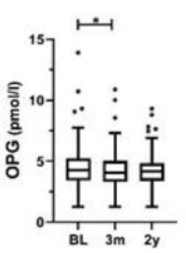

K

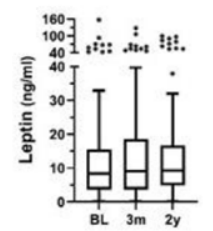

C

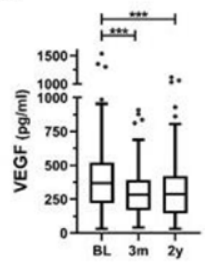

F

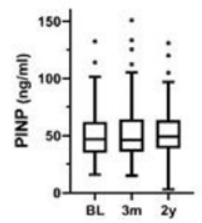

I

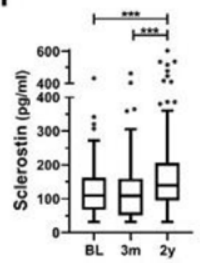

L

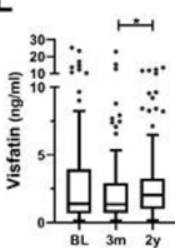

Figure. Levels of markers of inflammation (A-C), bone turnover markers (D-I) and adipokines (J-L) under treatment with TNF inhibitors: serum levels at baseline (BL; before start of TNFi), after 3 months $(3 \mathrm{~m})$ and 2 years $(2 \mathrm{y})$ of treatment. Wilcoxon Signed Rank Test: ${ }^{\star} \mathrm{p}$ value $<0.05 ;{ }^{\star \star} \mathrm{p}$ value $<0.01 ;{ }^{\star \star \star} \mathrm{p}$ value $<0.001$

Acknowledgements: Dr. Judith Rademacher is participant in the BIH-Charité Clinician Scientist Program funded by the Charité -Universitätsmedizin Berlin and the Berlin Institute of Health.

Disclosure of Interests: Judith Rademacher: None declared, Mark Siderius: None declared, Laura Gellert: None declared, Freke Wink Consultant of: AbbVie, Maryna Verba: None declared, Fiona Maas: None declared, Lorraine M Tietz: None declared, Denis Poddubnyy: None declared, Anneke Spoorenberg Consultant of: Abbvie, Pfizer, MSD, UCB, Lilly and Novartis, Grant/research support from: Abbvie, Pfizer, UCB, Novartis, Suzanne Arends Grant/research support from: Pfizer. DOI: 10.1136/annrheumdis-2021-eular.3059

\title{
POS1003 CATASTROPHIZING IN PATIENTS WITH SPONDYLOARTHRITIS
}

B. Coste ${ }^{1}$, C. Traverson ${ }^{1}$, E. Filhol ${ }^{1,2}$, C. Lukas ${ }^{2,3}$, S. Laurent-Chabalier ${ }^{4}$, J. Morel ${ }^{3,5}$, B. Combe ${ }^{3,5}$, C. Daien ${ }^{3,5}$, C. Hua ${ }^{1,2}$, C. Gaujoux-Viala ${ }^{1,2}{ }^{1} N$ îmes University Hospital, Rheumatology, Nîmes, France; ${ }^{2}$ University of Montpellier, IDESP, UMR-INSERM, Montpellier, France; ${ }^{3} \mathrm{CHU}$ Lapeyronie, Rheumatology, Montpellier, France; ${ }^{4}$ Nîmes University Hospital, BESPIM, Nîmes, France; ${ }^{5}$ University of Montpellier, -, Montpellier, France

Background: Catastrophizing is a negative cognitivo-affective response to an anxiety-provoking stimulus, especially anticipated or actual pain. It can be assessed quickly using a validated questionnaire: the Pain Catastrophizing Scale (PCS) ${ }^{1}$. Catastrophizing plays a role in maintaining chronic pain and is associated with several pain-related outcomes in osteoarthritis and low back pain. There is a lack of knowledge about catastrophizing in axial spondyloarthritis (AS) with only one study ${ }^{2}$ so far.

Objectives: To assess the prevalence of catastrophizing and associated factors in spondyloarthritis.

Methods: We performed an observational, prospective, bi-centric study. All patients aged 18 or over with AS fulfilling the 2009 Assessment in Spondyloarthritis International Society (ASAS) criteria were consecutively included. Sociodemographic data, information on the disease and its treatments were collected as well as questionnaires regarding disease activity (BASDAI), function (HAQ, BASFI), quality of life (SF12,

EQ5D), anxiety and depression (HADS, GAD7), fibromyalgia (FiRST), insomnia (ISI) and catastrophizing scores (PCS). Statistical analysis included a samples t-test, oneway variance analysis, Spearman's correlation coefficient, the $\mathrm{Chi}^{2}$ test, Fisher's exact test, the Wilcoxon test, multivariate linear regression (considering catastrophizing as a continuous variable) and multivariate logistics regression (considering catastrophizing as a categorical variable: PCS $\geq 20=$ high level catastrophizing).

Results: From September 2019 to March 2020, 168 AS patients were included: 48.5\% were women, the median age was 48.5 years and 100 patients $(60.2 \%)$ were professionally active. Almost all patients (95.8\%) had a disease lasting for more than 2 years; $110(72 \%)$ were HLA-B27+; 84 (50\%) had MRI sacroilitis and 62 (37.6\%) radiographic sacroiliitis. In all, $166(98.8 \%)$ had axial involvement, $99(58.9 \%)$ had peripheral involvement and $44(26.2 \%)$ had enthesitic involvement. The median BASDAI score was 6.30 [Q1-Q3 4.65-6.30].

The prevalence of a PCS score $\geq 20$ was $45.5 \%$ [38.0;53.0]. The median PCS score was 18 [7-27]. In multivariate logistics regression, high-level catastrophizing was significantly associated with the HADS anxiety score (OR=1.54 [1.22-2.0]), HADS depression score $(\mathrm{OR}=1.25$ [1.10-1.43]) and disease activity (BASDAI OR=1.14 [1.011.26]). In multivariate linear regression, catastrophizing was also significantly associated with anxiety $(p<0.0001)$, depression $(p<0.0001)$ and disease activity $(p=0.0008)$. Conclusion: Almost half the patients with AS were high catastrophizers. Catastrophizing is linked to anxiety, depression, and disease activity. It may be interesting to detect catastrophizing in order to improve the management of our patients.

\section{REFERENCES:}

[1] Sullivan MJL. et al. Psychological Assessment. 1995;7(4):524-32

[2] Penhoat M. et al. Joint Bone Spine. 2014;81(3):235-9

Disclosure of Interests: None declared.

DOI: 10.1136/annrheumdis-2021-eular.3171 \section{\begin{tabular}{l}
\hline POS1004 \\
BOTH SPONDYLOARTHRITIS AND PSORIATIC \\
ARTHRITIS PATIENTS HAVE STRONG FAMILY
\end{tabular} HISTORIES}

G. K. Yardımcı ${ }^{1}$, B. Farisoğulları ${ }^{1}$, E. C. Bolek ${ }^{1}$, E. Bilgin ${ }^{1}$, E. Duran ${ }^{1}$, G. Ayan ${ }^{1}$, Z. Özsoy ${ }^{1}$, G. Sandal Uzun ${ }^{1}$, L. Kılıç ${ }^{1}$, A. Akdoğan ${ }^{1}$, O. Karadag ${ }^{1}$, Ş. A. Bilgen ${ }^{1}$, A. İ. Ertenli ${ }^{1}$, U. Kalyoncu ${ }^{1}$, S. Kiraz ${ }^{1} .{ }^{1}$ Faculty of Medicine; Hacettepe University, Rheumatology, Ankara, Turkey

Background: Family history is one of the hallmarks of spondyloarthritis (SpA) and psoriatic arthritis (PsA) [1, 2]. Some patients have a strong family history that more than 2 relatives have spondyloarthritis related diseases. The effects of strong family history on SpA features were not known very well.

Objectives: The aim of this study is to evaluate the effects of family history in SpA and PsA patients.

Methods: HUR-BIO (Hacettepe University Biologic Registry) is a prospective, single center database of biological treatments since 2005, and to date $3071 \mathrm{SpA}$ and 526 PsA patients have been recorded. Demographic, clinical characteristics, disease activity parameters, a detailed family history of SpA and SpA features (presence of SpA including PsA, psoriasis, inflammatory bowel disease and uveitis) and laboratory data before anti-TNF treatments of the patients were noted.

Results: 2807 SpA (53.6\% male) and 506 PsA (31.4\% male) patients' family history were available and analysed. A positive family history was noted in $27.6 \%$ of the SpA and $31.0 \%$ of the PsA patients (ns). $7.4 \%$ of the SpA patients and $8.9 \%$ of the PsA patients had family history in more than one relative (Table 1). In SpA patients with a family history, uveitis was more frequent than patients without (14.4\% vs $10.6 \%, p=0.006)$. Except for a higher male predominance and uveitis $(53 \%$ vs $32 \%$ $\mathrm{p}=0.006$ and $9 \%$ vs $2 \% \mathrm{p}=0.003$ respectively) in patients with $\geq 2$ relatives with $\mathrm{SpA}$ features, there were no differences in PsA patients regarding family history. The presence of family history and HLA-B27 (63.7\% vs 37.6\%, p<0.001) positivity were associated in SpA patients but not in PsA patients (31.2\% vs $20.0, p=0.13$ ).

Conclusion: Family history was present in about one third of the patients of PsA and $\mathrm{SpA}$. It is not uncommon for two or more family members to have a SpA feature. Presence of family history may be associated with some clinical conditions, such as uveitis. REFERENCES:

[1]Solmaz, D., et al., Impact of Having Family History of Psoriasis or Psoriatic Arthritis on Psoriatic Disease. Arthritis Care Res (Hoboken), 2020. 72(1): p. 63-68.

[2] Zurita Prada, P.A., et al., Influence of smoking and obesity on treatment response in patients with axial spondyloarthritis: a systematic literature review. Clin Rheumatol, 2020.

Table 1. Family history in PsA and SpA patients

\begin{tabular}{|c|c|c|}
\hline & PsA $(n=506)$ & SpA $(n=2807)$ \\
\hline $\begin{array}{l}\geq 1 \text { family history, } n(\%) \\
\geq 1 \text { first-degree relative, } n(\%) \\
\geq 2 \text { first-degree relatives, } n(\%) \\
\geq 2 \text { relatives (both first- and second-degree), } n(\%) \\
\text { Family history }\end{array}$ & $\begin{array}{l}157(31.0) \\
114(22.5) \\
21(4.2) \\
45(8.9)\end{array}$ & $\begin{array}{l}774(27.6) \\
489(17.4) \\
77(2.7) \\
208(7.4)\end{array}$ \\
\hline $\begin{array}{l}>\text { Psoriasis, } \mathbf{n}(\%) \\
>\text { Psoriatic arthritis, } \mathbf{n}(\%) \\
>\text { Spondyloarthritis, } \mathbf{n}(\%) \\
\text { > Inflammatory bowel disease, } \mathrm{n}(\%) \\
\text { > Uveitis, } \mathrm{n}(\%)\end{array}$ & $\begin{array}{l}120(23.7) \\
14(2.8) \\
38(7.5) \\
1(0.2) \\
0\end{array}$ & $\begin{array}{l}155(5.5) \\
9(0.3) \\
643(22.9) \\
10(0.4) \\
2(0.1)\end{array}$ \\
\hline
\end{tabular}


Disclosure of Interests: None declared.

DOI: 10.1136/annrheumdis-2021-eular.3330

\section{POS1005 ASSESSMENT OF DAREA AND MODIFIED DAREA IN AN ARGENTINIAN-GUATEMALAN REACTIVE ARTHRITIS COHORT}

M. Benegas ${ }^{1}$, C. Orozco ${ }^{2}$, P. Giorgis ${ }^{2}$, E. E. Schneeberger ${ }^{2}$, J. M. Bande ${ }^{3}$, M A. Medina ${ }^{4}$, I. Iraheta ${ }^{5}$, C. Airoldi ${ }^{6}$, P. Girard Bosch ${ }^{7}$, S. Scarafia ${ }^{8}$, E. Velozo ${ }^{9}$, O. Rillo ${ }^{10}$, M. Guinsburg ${ }^{11}$, M. P. Cowan ${ }^{12}$, M. Piovesan ${ }^{12}$, V. Martire, L. Casalla ${ }^{12}$, V. Cosentino ${ }^{13}$, P. Gonzalez ${ }^{14}$, C. Peon ${ }^{14}$, R. Gomez ${ }^{14}$, A. Benitez ${ }^{14}$, M. J. Gamba ${ }^{14} .{ }^{1}$ Sanatorio Méndez, Reumatologia, CABA, Argentina; ${ }^{2}$ Instituto de Rehabilitación psicofísica, Reumatologia, caba, Argentina; ${ }^{3}$ Hospital tornú, Reumatologia, CAB, Argentina; ${ }^{4}$ Hospital tornú, Reumatologia, CABA, Argentina; ${ }^{5}$ Asociación Guatemalteca antienfermedades reumáticas, Reumatologia, Guatemala, Guatemala; ${ }^{6}$ Hospital Provincial de Rosario, Reumatologia, Rosario, Argentina; ${ }^{7}$ Instituto médico platense, Reumatologia, La plata, Argentina; ${ }^{8}$ Hospital Municipal de San Fernando, Reumatologia, Buenos Aires, Argentina; ${ }^{9}$ Sanatorio y Universidad Adventista del Plata, Reumatologia, Entre Rios, Argentina; ${ }^{10}$ Hospital Pirovano, Reumatologia, CABA, Argentina; ${ }^{11}$ Hospital Glassman, Reumatologia, Bahia Blanca, Argentina; ${ }^{12}$ Consultorio privado, Reumatologia, CABA, Argentina; ${ }^{13}$ Hospital Ramos Mejía, Reumatologia, CABA, Argentina; ${ }^{14}$ Hospital Alejandro Posadas, Reumatologia, Buenos Aires, Argentina

Background: Reactive Arthritis $(\mathrm{Re} A)$ is an inflammatory joint disease and, as in rheumatoid or psoriatic arthritis, composite indices are the most useful tools to measure disease activity. The Disease Activity Index for Reactive Arthritis (DAREA) is the only developed index for ReA, which requires a 66/68 joint count and CRP for its assessment, the latter being difficult to acquire in our setting. Therefore, we developed a simplified index, the modified DAREA (DAREAm), with a lower joint count and ESR for its evaluation.

Objectives: 1) To evaluate the DAREA and the DAREAm in a cohort of patients with diagnosis of $\mathrm{ReA}$ and post-infectious arthritis 2) To assess the correlation of the DAREA and DAREAm with several clinical variables, functional capacity and quality of life in a cohort of patients with ReA.

Methods: Patients with diagnosis of ReA (Calin'79) and post-infectious arthritis were included. Demographic data were collected, patient's pain and global assessment were evaluated through a visual analog scale (VAS) and a 3-point scale (no pain $=0$, mild $=1$, moderate $=2$, severe $=3$ ), physician's global assessment, morning stiffness (MS) and VAS fatigue. Functional capacity was assessed by $H A Q$ and quality of life according to EuroQol-5 dimensions (EQ-5D), and the activity indices DAS28, DAREA and DAREAm were calculated. Statistical analysis: a descriptive analysis of the variables and correlation between numerical variables with Spearman rank correlation were performed. Results: 57 patients were included, 53 with diagnosis of $\mathrm{ReA}$, the majority post urogenital $(63 \%)$ and gastrointestinal (17\%), and 4 with diagnosis of post-infectious arthritis. Fifty six percent were male, mean age: 40 years old $(S D \pm 14)$ and median ReA duration: 15 months (IQR 2-45). The number of painful and swollen joints in a 66/68 joint count showed a median of 2 (IQR 0-3) and 1 (IQR 1-2) respectively. Median VAS pain 43 (IQR 15-70), patient's disease activity 40 (IQR 20-60) and physician's 40 (IQR 20-60), MS 10 (IQR 0-50) and fatigue 30 (IQR 0-80). Median DAS28 3.6 (IQR 2.3-4.3), DAREA 7.4 (IQR 2.5-10.6), DAREAm 8.6 (IQR 4.6-12.7), HAQ 0.625 (IQR 0.125-1). The dimensions with the greatest compromise in the EQ-5D were pain/discomfort $(63 \%)$ and anxiety/ depression (51\%), and the median VAS EQ-5D was 60 (IQR 32-80). DAREA correlated with DAREAm ( $r s=0.89 ; p<0.001)$, DAS28 ( $r s=0.84 ; p<0.001)$, medical VAS $(r s=0.60$; $p<0.001)$, MS ( $r s=0,50 ; p<0.001), H A Q(r s=0.53 ; p<0.001)$, VAS fatigue ( $r s=0.57 ; p$ $<0.001)$ and mobility subscales of the EQ5D ( $r s=0.56$; $p<0.001)$, pain/discomfort $(r s=$ $0.49 ; p<0.001$ ) and anxiety/depression ( $r s=0.61 ; p<0.001$ ). The DAREAm correlated with DAS28 ( $r s=0.93 ; p<0.001$ ), physician VAS ( $r s=0.58 ; p<0.001)$, fatigue VAS $(r s=$ $0.53 ; p<0.001), \mathrm{HAQ}(\mathrm{rs}=0.51 ; \mathrm{p}<0.001)$ and the EQ5D subscales: mobility ( $r s=0.64 ; \mathrm{p}$ $<0.001$ ), pain/discomfort ( $r s=0.56 ; p<0.001)$ and anxiety/depression ( $r s=0.66 ; p<0.001$ ) Conclusion: This is the first study that assess activity indices in a cohort of patients with ReA. The DAREAm demonstrated a very good correlation with both DAREA and DAS28. We encourage the use of this simplified index in daily practice to evaluate patients with $R e A$. Disclosure of Interests: None declared.

DOI: 10.1136/annrheumdis-2021-eular.3374

\section{\begin{tabular}{|l|l}
\hline POS1006 & ABERRANT TH17 CELLS EXPANSION AND RISK \\
\hline
\end{tabular} FACTORS IN ANKYLOSING SPONDYLITIS PATIENTS COMPLICATED WITH CARDIOVASCULAR EVENTS}

T. Ding ${ }^{1}$, B. C. $\mathrm{LI}^{2}$, R. Su${ }^{2}$, X. F. LI' ${ }^{2}$, C. Wang ${ }^{2} .{ }^{1}$ The Second Hospital of Shanxi Medical University, Rheumatology, Taiyuan, China; ${ }^{2}$ Rheumatology, The Second Hospital of Shanxi Medical university, Taiyuan, China, Rheumatology, Taiyuan, China

Background: The incidence of Ankylosing Spondylitis (AS) complicated with cardiovascular diseases (CVD) has increased in recent years [1]. However, identification of risk factors indicating the development of CAD in AS patients is lacking. Th17 cells are increasingly recognized to be important in atherogenesis
[2]. However, the role of these cells in the pathogenesis of ankylosing spondylitis patients complicated with cardiovascular events remains elusive.

Objectives: This study aimed to assess the level of circulating Th17 cells as well as other lymphocyte subsets such as Treg, Th, Ts, and NK cells in AS combined with CVD, and further to evaluate whether elevations in special PBMC subpopulations in AS patients indicate an increased risk of CVD.

Methods: Samples were assessed from 141 AS patients hospitalized at the Second Hospital of Shanxi Medical University (60 AS patients combined with CVD and 81 AS patients without CVD) and 100 healthy controls. The absolute numbers of lymphocytes and CD4+ T cells in peripheral blood were determined using Flow Cytometer. The association between PBMC subpopulations and CVD development in AS patients were analyzed using multivariable logistic regression. Results: 1. Compared with AS group, AS with CVD group exhibited significant increases in the number of Th17 cells $(P=0.001)$ and Treg cells $(P=0.046)$. The ratio of Th17/Treg was also increased $(P=0.085)$.

2. Analogous increases in the absolute number $(P<0.001)$ and frequency $(P<0.001)$ of Th1 cells, as well as the ratio of Th1/Th2 $(P<0.001)$ and Th1/Treg $(P=0.004)$ were also present in AS with CVD patients, compared to those without CVD. 3. Compared to HCs, 141 AS patients showed significantly decreased Treg cells $(P<0.012)$ and increased Th17/Treg $(P=0.001)$.

4. Logistic regression showed age (odds ratio: $1.09 ; 95 \% \mathrm{Cl}: 1.035-1.137$ ), hypertension (odds ratio: $3.31 ; 95 \% \mathrm{Cl}$ : $1.152-9.528$ ), diabetes (odds ratio: $8.03 ; 95 \%$ $\mathrm{Cl}: 1.251-51.503$ ), and elevated level of Th1 number (odds ratio: $1.01 ; 95 \% \mathrm{Cl}$ 1.003-1.016) and DD (D-dimer) (odds ratio: 1.00; 95\% Cl: 1.000-1.002) were significantly correlated with the onset of CVD in AS patients.

5. Smoke, increased Th17 level, and use of NSAIDS were also positively correlated with the onset of CVD although the P-values did not reach significant. Conclusion: Our data indicates aberrant expansion of Th17 cells in AS with CVD patients. Moreover, age, hypertension, diabetes, and increased level of Th1 in PBMC and $\mathrm{DD}$ are single independent risk factors for the presence of CVD in AS. The mechanisms of atherogenesis in AS may associate with the elevations in Th1 and Th17 cells. Imbalance of Th1/Th2 and Th17/Treg may be shared etiologic pathways of AS and CVD, providing attractive targets for the prevention and therapy of CVD development in AS patients.

\section{REFERENCES:}

[1] Kim JH, Choi IA. Cardiovascular morbidity and mortality in patients with spondyloar thritis: A meta-analysis. Int J Rheum Dis (2020). doi: 10.1111/1756-185x.13970.

[2] Saigusa R, Winkels $H$, Ley K. T cell subsets and functions in atherosclerosis Nat Rev Cardiol. 2020 Jul;17(7):387-401. doi: 10.1038/s41569-020-0352-5.
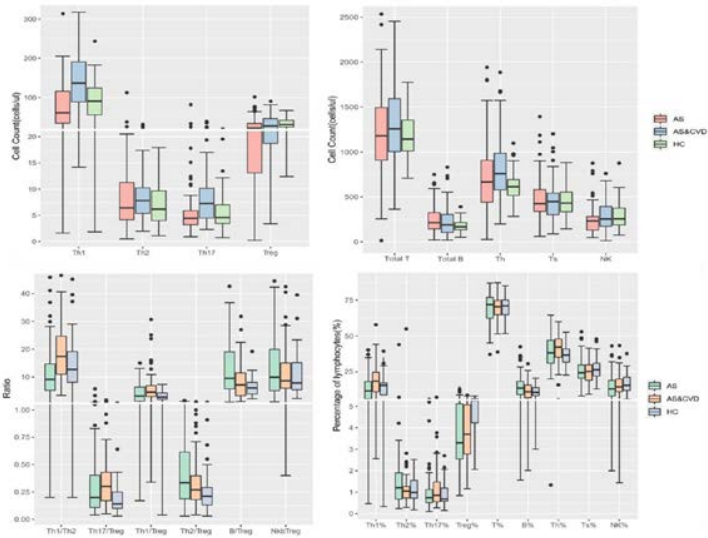

Figure 1. Compared with AS group, AS with CVD group exhibited significant increases in the number of Th17 cells $(P=0.001)$ and Treg cells $(P=0.046)$. The ratio of Th17/Treg was also increased $(P=0.085)$. The absolute number $(P<0.001)$ and frequency $(P<0.001)$ of $T h 1$ cells, as well as the ratio of Th1/Th2 $(P<0.001)$ and Th1/Treg $(P=0.004)$ were also present in AS with CVD patients.

Disclosure of Interests: None declared

DOI: 10.1136/annrheumdis-2021-eular.3442

POS1007

OPTIMIZING A REFERRAL STRATEGY FOR PATIENTS WITH A HIGH PROBABILITY OF AXIAL SPONDYLOARTHRITIS: THE ROLE OF AGE AND SYMPTOM DURATION

$\underline{\text { F. Proft }}{ }^{1}$, L. Spiller ${ }^{1}$, B. Muche ${ }^{1}$, M. Protopopov ${ }^{1}$, J. Rademacher ${ }^{1}$, V. Rios Rodriguez ${ }^{1}$, M. Torgutalp ${ }^{1}$, D. Poddubnyy ${ }^{1}$, I. Redeker ${ }^{2} .{ }^{1}$ Charité Universitätsmedizin Berlin, Division of Gastroenterology, Infectious Diseases and Rheumatology; Department of Rheumatology, Berlin, Germany; ${ }^{2}$ German Rheumatism Research Centre; Deutsches Rheuma-Forschungszentrum Berlin (DRFZ);, Programmbereich Epidemiologie, Beerlin, Germany

Background: One of the most important prerequisites for a timely diagnosis of axia spondyloarthritis (axSpA) is the early referral of a patient with back pain to a rheumatologist. In the past years a number of referral strategies has been proposed, 